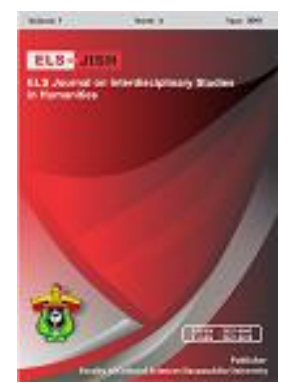

ELS-JISH

ELS Journal on Interdisciplinary Studies on Humanities

Volume 2 Issue 4, 2019

ISSN (print) : 2621-0843

ISSN (online) : 2621-0835

Homepage : http://journal.unhas.ac.id/index.php/jish

\title{
The Effects of Technological Abuse to Social Life as Reflected in Mary Shelley's "Frankenstein"
}

\author{
Muhammad Ardiansah ${ }^{1}$, Burhanuddin Arafah $^{2}$, Herawaty Abbas ${ }^{3}$ \\ 1'mulgokizary184@gmail.com
}

\begin{abstract}
Technology in the world of literature is still not too often discussed, but the fact is there are many things that can be discussed in technology such as its use, its history, its effects, its purpose, etc. and the most frequently discussed in the world of technology in the present is its effect. This study aims to describe and to elaborate the form of technological abuse effects to social life as reflected in Shelley's Frankenstein. The researcher used sociology literature approach to find out the forms of technological abuse effects to social life as reflected in the novel. The primary data were taken from Frankenstein novel and the secondary data were taken from library search including articles and journals. The researcher used note taking in collecting data. The result of this research found two forms of technological abuse effects to social life that are illustrated in the novel, namely: Anti Social and and Procrastination.
\end{abstract}

Keywords: Technological Abuse; Sociology of Literature; Frankenstein

How to cite: Ardiansah, M. (2019). The Effects of Technological Abuse to Social Life as Reflected in Mary Shelley's "Frankenstein". ELS Journal on Interdisciplinary Studies in Humanities, 2(4), 607-611

\section{Introduction}

Literary work is often referred to as something that is not real and also still often regarded as an imagination. But actually, literature is a reflection of a social condition that occurs around the writer. It is really interesting realizing that every literary work has a value contained in it and of course the value comes from the writer who is in a particular social life. The relationship between literature and society has been very close and inseparable.

According to Swingewood and Laurenson (1972:11) sociology and literature are quite distinct areas of research. However, at the most basic level, that of content, they share similar conspectus.

Spector and John I (1977:5) stated that literary work usually reveals situation or problems that occur in social life. The problems are called social problem. It is unusual condition or a form of behavior, which is considered to be deviated from the social norms. Furthermore, Culler, (1997:22) also argued that perhaps literature is like weed, which are simply plants that gardeners do not have growing in their

\footnotetext{
${ }^{1,2,3}$ Hasanuddin University, Indonesia 
gardens. Culler argues weed is similar with literature that keeps growing up by periods.

Technology in the world of literature is still not too often discussed, but the fact is there are many things that can be discussed in technology such as its use, its history, its effects, its purpose, etc. and the most frequently discussed in the world of technology in the present is its effect. The ability of technology to facilitate human activities makes people lazy to do something or even affect their brain, Andrew (2012) video games and screen technologies "digital drugs," many technologies are so stimulating, Doan says, that they raise levels of dopamine the feel-good neurotransmitter most commonly linked to addiction. Research, he says, shows that long amounts of time focused on a screen can affect the brain's frontal cortex the same way that cocaine does. "Depression, anxiety, and aggression have all been linked to excessive screen time, and can even spur psychotic-like features," he says. "Further research shows that as more kids use digital media, their social skills erode. And the more time a child spends dedicated to cyber-reality, the more they lose their ability to interpret real-life emotions."

In this proposal the researcher wants to reveal the effects that occur from technological abuse in Mary Shelley's Frankenstein by using Abram's theory sociology of literature

The researcher summarized Frankenstein that Mary Shelley introduced the novel with a man named Walton who meets Victor Frankenstein in the north pole, Victor then began to tell a story about his past to Walton, it was started when he was a child, he was a little different from his friends, he preferred to read books than playing with his friends, he liked to learn new things which made him very smart. After growing up he began to become obsessed with physics and chemistry he began to study alchemy on how to revive a dead person, and after two years of study he finally learned how to do it he knew what he was doing was wrong, and violated religion but he was blinded by the science and technology around him. He then uses the technology and the knowledge he has to bring the dead to life. But he did not know what the consequences would happen of his act. The effects of technological abuse by Victor gives us an explanation about how dangerous technology is when it is abused.

Furthermore, the researcher attempts to analyze and describe the effects of technological abuse by using the sociology of literature approach. Hence, the researcher decides the title of this thesis is The Effects of technological abuse in Social Life Reflected in Mary Shelley's Frankenstein.

\section{Method}

This study is categorized as a descriptive and qualitative research and for the analyzing of this work the researcher used the sociological approach. This study put the focus in analyzing the effects of technological abuse to social life in the novel. The data are presented in descriptive qualitative method.

The primary data are collected from Mary Shelley's "Frankenstein" through the character and characterization, the plot, and the setting of the story. 
The supporting data are collected from bibliographical data or referential data such as the various books and writings from the internet related to the subject matter of this research

\section{Analysis}

\subsection{The performances that Victor Frankenstein has applied to technological abuse to social life.}

Arthur (2009) stated that the first and most basic one is a technology is a means to fulfill a human purpose. As a means, a technology may be a method, knowledge, or process or device or it may be complicate or it may be material or it may be nonmaterial. Whichever it is, it is always a means to carry out a human purpose."

From the definition of technology described above, we can know that technology is not a small scope about sophisticated machines or sophisticated tools, but methods, knowledge, and even a process that aims to provide convenience to humans can be called technology.

Technology can be called abused if the technology is not used for its intended purpose or used excessively which can even have a negative effect on users and others. Universal Theory by Abrams M.H. (Abram, 1953)

In this research the form technological abuse carried out by Victor Frankenstein in this novel is not from a machine but from the knowledge he has gathered.

"Before this I was not unacquainted with the more obvious laws ofelectricity. On this occasion a man of great research in natural philosophy was with us, and excited by this catastrophe, he entered on the explanation of a theory which he had formed on the subject of electricity and galvanism" (1818:38)

The description above shows that with his interest in what happens to the trees affected by lightning, Victor Frankenstein also tries to learn how electrical science works and also the theory of galvanism. In biology, galvanism is the contraction of a muscle that is stimulated by an electric current

"In this mood of mind I betook myself to the mathematics and the branches of study appertaining to that science as being built upon secure foundations, and so worthy of my consideration." (1818:39)

The description above shows that after mastering the science of electricity and knowing how electricity can make contractions in muscles Victor Frankenstein then tried to study Science and Mathematics to find out the basis of the knowledge he would do in the future.

Based on the two data above we can clearly see how Victor continued to deepen his knowledge but he did not use it according to the intended purpose of the technology but he abused the technology for his personal purpose which was an act against God.

"One of the phenomena which had peculiarly attracted my attention was the structure of the human frame, and, indeed, any animal endued with life. Whence, I often asked myself, did the principle of life proceed? It was a bold question, and one which has ever been considered as a mystery" $(1818: 51)$ 
The description above shows that Victor Frankenstein then studied the structure of human anatomy and how the structure of human beings formed a unity

\subsection{The Effects of technological abuse to Social Life.}

Technology has changed the way people interact with others in their daily lives, and it has been proven to be one of the reasons why someone has a problem in socializing, the technological abuse that occurs in various places around the world has illustrated how people who abuse technology tend to be solitary because they are addicted in doing their activities from those technologies.

From previous findings we can know that before victor Frankenstein do the technological abuse he is someone who has good social skills, and is able to socialize well with anyone, he has a friend who he said himself that he has a deep bond with him and also when he had just moved to Ingosdalt, he was able to socialize well with his lecturers quickly. But after he abuses technology we can see a drastic change in his behavior in social life that is he becomes Anti-social and Procrastination.

\section{Anti-Social}

The first effect of the technological abuse to social life is difficult to socialize directly and not care about the surroundings. This is because the technological abuse makes people addicted so they are lazy to socialize.

Anti-Social is a person who was previously able to socialize but because of a certain situation it made him hard to socialize, usually because of the busyness of new things which made him forget his friends and family. this type tends to happen to people who follow the latest trends and keep up with technology.

"The summer months passed while I was thus engaged, heart and soul, in one pursuit. It was a most beautiful season; never did the fields bestow a more plentiful harvest or the vines yield a more luxuriant vintage, but my eyes were insensible to the charms of nature" (1818:56)

The description above shows that Victor Frankenstein no longer socialize with other people in his environment and he begins to shut himself down and does not care about the circumstances that occur around him.

"And the same feelings which made me neglect the scenes around me caused me also to forget those friends and family who were so many miles absent, and whom I had not seen for so long a time. (1818:57)

The description above shows that Victor Frankenstein had forgotten the people closest to him which is his friends and family. The description above shows that Victor Frankenstein has become an Anti-Social Person type 3

\section{Procrastination}

The second effect of the technological abuse in social life is always postponing work that should be completed as soon as possible. Technology addiction makes users lazy to carry out their responsibilities and prefer to continue their activities with these technologies.

Ferrari (1995:74) described procrastinators as people who are lazy, spoiled, and unable to regulate themselves. Conversely, people who are not procrastinators 
are considered as people who have high efficiency and productivity and superior performance

High level procrastination. In this type the impact of the delay carried out not only affects the quality of his work but also the quality of his life. Irregular lifestyle, low drop out and relationship.

"I knew my silence disquieted them, and I well remembered the words of my father: "I know that while you are pleased with yourself you will think of us with affection, and we shall hear regularly from you. You must pardon me if I regard any interruption in your correspondence as a proof that your other duties are equally neglected."(1818:56)

The description above shows that his father ever told him to always write him a letter to know if he's alright or not, but he even no longer listened to his father's orders, he chooses to ignore it and postpone it which makes him become a procrastinator.

\section{Conclusion}

Mary Shelley is an English novelist who wrote the Gothic novel Frankenstein; or, The Modern Prometheus (1818). In penning her Gothic novel, Shelley was writing the first major science fiction novel, as well as inventing the concept of the "mad scientist" and helping establish what would become horror fiction. The influence of the book in popular culture is so huge that the term "Frankenstein" has entered common speech to mean something unnatural and horrendous.

In the novel of "Frankenstein"Mary Shelley describes an effect of technological abuse to social life. Which is done by the main protagonist Victor Frankenstein.From the character of "Frankenstein" who has committed technological abuse we can realize the danger that occurs to someone who has addicted withtechnological abuse, especially to their social life the condition startwhen the person becomes an anti-social and does not like to socialize, people who is effected by the effect tend to like to be alone and do not want to interact with other people.

\section{References}

Abram, M. H. (1953). The Mirror and The Lamp. London: Oxford University Press Inc.

Andrew, D. (2012). Hooked on Games The Lure and Cost of Video Game and Internet Addiction. United States I: FEP Internationa.

Arthur, W. B. (2009). The Nature of Technology. United States: Free Press.

Culler, J. (1997). Literary theory, a Very Short Introduction. New York: Oxford University Press.

Ferrari, J. (1995). Procrastination and Task Avoidance--Theory, Research and Treatment. Kansas: Plenum Press.

Spector, M., \& John I, K. (1977). Constructing Social Problem. Menlo park, Calif: Cummings Pub.co.

Swingewood, A., \& Laurenson. (1972). The Sociology of Literature. London: Paladin. 